on a 25 year contract affecting supplies of 350 million cubic feet of gas a day. This is much like the figure which has been widely quoted since negotiations started eighteen months ago, with perhaps a slight upward revision because of the effects of devaluation. The original contract signed with British Petroleum at $5 d$. a therm for 100 million cubic feet a day was obviously not going to be repeated-equally, the Gas Council's original offer of $1 \cdot 8 d$. per therm was probably unrealistically low. Both Phillips and the Gas Council seem now to be satisfied.

This is entirely as one would expect. Despite accepting a price which some would consider low, Phillips is going to make a very handy profit. When the gas is flowing at full speed through the pipes, it will be collecting $£ 1$ million about every three and a half weeks. The investment probably cost $£ 25$ million, a sum which it will earn within two or three years. After that, all being well, it will be pure profit. But it is only fair to point out that it may not be quite so easy-the field may need further development in order to keep the gas flowing. And Phillips can fairly claim that without a generous return it would never have made the investment in the first place.

With luck, the agreement with Phillips will encourage the other companies involved to come to terms. Arpet, which shares Phillips's field on the Hewett Bank, must surely now settle on the same terms. And the other companies, Shell/Esso and Amoco (which shares its find with the Gas Council), must also now knuckle under. These finds are somewhat farther out in the North Sea, and rather deeper, so that Shell/Esso and Amoco may be able to squeeze a little more out of the Gas Council. But it is now the Gas Council which is the master, principally because the reserves of gas which have been found far outstrip demand. Even the Phillips find will be enough to supply onethird of present British demand for gas. By 1971, demand is expected to double, but even so there is likely to be something of a glut of natural gas for a decade or so. The oil companies negotiating with the Gas Council thus find themselves in a conspicuously weak position which no amount of bluster can conceal.

This should also have the effect of strengthening the case put forward by the Central Electricity Generating Board for a greater share of the gas. If the CEGB wins its case-and in the long run it can hardly failthe principal loser will again be coal. But nuclear power, just emerging from a long and bitter struggle with the coal lobby, may now find itself embroiled in a similar struggle with gas. For the ordinary gas consumer, the Gas Council can only promise jam tomorrow. In the short term, it says, gas prices are certain to rise, in part because of the crisis in the Middle East. In the long run, Sir Henry Jones of the Gas Council thinks gas prices will fall, but less optimistic observers fear that natural gas will do no more than prevent an upward spiral in prices. To the domestic consumer, paying almost ten times as much as the Gas Council is paying Phillips for each therm of gas (the average price of gas to the consumer is about $25 \cdot 5 d$. per therm), this seems very hard to accept.

\section{Exploiting Technology}

THe role of public research and development services in British technology has been evaluated by the
Institution of Professional Civil Servants, and recommendations for improvements are published this week in a report entitled Exploiting Technology. The executive committee of the institution decided to look into the way research and development in the public sector are operating, with the belief that it could make proposals for action as well as examining the facts. The 70,000 members of the institution work in all branches of the public sector-government departments, public bodies, and with the research councils.

The report begins with the assumption that research and development are the key to any nation's prosperity, and Britain is not making the best use of its resources in this direction. Left to itself, industry does not under. take the necessary research and development, and although there are various forms of government encouragement--through such bodies as the Industrial Re-organization Corporation, the National Research Development Corporation and research associations and advisory services-there is scope for much more. The report discusses suggestions that more research and development should be taken from the public sector by industry, and concludes that little would be gained from this, as ideas are often badly thought out or too long-term to be of practical value in the near future. Any shake-out of staff from the public sector would in fact have very little effect in industrial research. Buildings, equipment and experienced staff are already in existence in the public sector, but although many of the organizations have been doing a good job, the report suggests that most of them could be effectively streamlined.

In its recommendations, the report calls first of all for a clear statement of priorities from the Government, so that money is not wasted on research that is too expensive or will shortly be abandoned. After this, closer cooperation between public sector research and industry is the main theme. Rationalization of organizations doing similar research work and industries with similar problems is called for, together with closer working of public bodies with industry so that research teams investigating problems in industry and industrialists are brought into research councils and the management of government establishments. A central body, organized by the government, should take charge of the coordination of scientific and technical information and its dissemination, but commercial security must be safeguarded. Exchanges of manpower are desirable, and the report suggests that mobility can be encouraged by workers having transferable pension schemes. Refresher courses are recommended for qualified staff, and it is suggested that firms will benefit if scientists and engineers are trained in management techniques. With the realization that streamlining of the public sector will affect members of the institution, the report states that there must be adequate preparation for the social problems involved in the changes of employment resulting from this reorganization.

\section{Doctorates in Physics}

THE Royal Society has just published a report on the training of PhD students in physics. The report forms part of a Royal Society survey, started in November 1965 , on postgraduate training in science and technology in the United Kingdom. Sub-committees were set up to investigate the content and quality of training 